\title{
Contemporary ventilation strategies and adjunctive therapies for acute respiratory distress syndrome (ARDS)
}

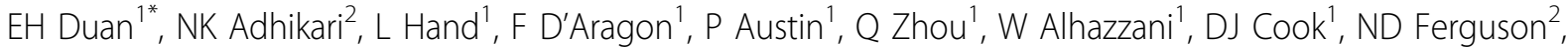 \\ MO Meade', Canadian Critical Care Trials Group
}

From ESICM LIVES 2015

Berlin, Germany. 3-7 October 2015

\section{Introduction}

Over the past 5 years, several interventions have been shown in randomized clinical trials (RCTs) to reduce mortality in patients with ARDS. The current use of these interventions in clinical practice, along with those of unproven benefit, is unknown.

\section{Objectives}

To determine which ventilation strategies and adjunctive treatments clinicians use for moderate-severe ARDS, and which ones they use as rescue therapy in refractory hypoxemia.

\section{Methods}

We conducted a 12-month observational study (2014/032015/02) in 23 Canadian and 1 Saudi Arabian intensive care units (ICUs) that had participated in the OSCILLATE RCT of high frequency oscillation (HFO). We included mechanically ventilated adults with moderate-severe ARDS (Berlin criteria), defined by $\mathrm{PaO}_{2} / \mathrm{FiO}_{2} \leq 200$ with positive end-expiratory pressure (PEEP) $\geq 5 \mathrm{cmH}_{2} \mathrm{O}$, and who also required a $\mathrm{FiO}_{2} \geq 0.50$. Consecutive patients were prospectively identified and we collected baseline demographics, daily ventilation settings and adjunctive therapies for ARDS up to ICU day 28 , and hospital outcomes.

\section{Results}

These preliminary results include data from 533 patients. On day 1 of ARDS diagnosis, the most common ventilator modes were pressure control $(\mathrm{n}=222,42 \%)$ and volume control $(\mathrm{n}=123,23 \%)$. The mean $\mathrm{FiO}_{2}$ was 0.74

${ }^{1}$ McMaster University, Hamilton, Canada

Full list of author information is available at the end of the article
$(\mathrm{SD}=0.21)$, tidal volume $7.4 \mathrm{ml} / \mathrm{kg}(\mathrm{SD}=2.2)$ predicted body weight $(\mathrm{PBW})$, plateau pressure $26(\mathrm{SD}=7) \mathrm{cmH}_{2} \mathrm{O}$ and PEEP $11(\mathrm{SD}=4) \mathrm{cmH}_{2} \mathrm{O}$. One-third of patients $(155 / 466)$ were ventilated with tidal volume $>8 \mathrm{ml} / \mathrm{kg}$ PBW on day 1 . In all patients, the most common respiratory adjuncts used were neuromuscular blocking agents (NMBA) $(\mathrm{n}=204,38 \%)$, corticosteroids $(\mathrm{n}=139,26 \%)$, pulmonary vasodilators $(\mathrm{n}=88,17 \%)$, prone positioning $(\mathrm{n}=48,9 \%)$, HFO $(\mathrm{n}=24,5 \%)$ and extracorporeal life support (ECLS) $(\mathrm{n}=23,4 \%)$. Among 82 patients with refractory hypoxemia, defined as a sustained $\mathrm{PaO}_{2} \leq 60$ mmHg on $\mathrm{FiO}_{2}$ 1.0, use of adjuncts increased: NMBA $(\mathrm{n}=52,63 \%)$, pulmonary vasodilators $(\mathrm{n}=39,48 \%)$, corticosteroids $(\mathrm{n}=26,32 \%)$, prone positioning $(\mathrm{n}=21,26 \%)$, $\operatorname{HFOV}(\mathrm{n}=14,17 \%)$ and ECLS $(\mathrm{n}=10,12 \%)$. Median length of mechanical ventilation was $9(\mathrm{IQR}=4,17)$ days and ICU length of stay was $11(\mathrm{IQR}=6,20)$ days. ICU mortality was $46 \%(225 / 491)$ overall, and higher $(63 \%$, $49 / 78$ ) among patients with refractory hypoxemia. Withdrawal of life support preceded $36 \%$ of deaths $(n=80)$.

\section{Conclusions}

Clinicians generally utilized low tidal volume ventilation, although in many patients the recommended threshold was exceeded. Initial PEEP levels were lower than those used in high PEEP arms of several RCTs. HFOV was used infrequently in these centres. The most common respiratory adjunct was NMBAs. Despite stronger RCT evidence to support prone positioning, it was employed infrequently.

\section{Grant Acknowledgment}

Funded by the Canadian Institutes of Health Research. 


\section{Authors' details}

${ }^{1}$ McMaster University, Hamilton, Canada. ${ }^{2}$ University of Toronto, Toronto,

Canada.

Published: 1 October 2015

doi:10.1186/2197-425X-3-S1-A6

Cite this article as: Duan et al:: Contemporary ventilation strategies and

adjunctive therapies for acute respiratory distress syndrome (ARDS).

Intensive Care Medicine Experimental 2015 3(Suppl 1):A6.

\section{Submit your manuscript to a SpringerOpen ${ }^{\mathcal{O}}$ journal and benefit from:}

- Convenient online submission

- Rigorous peer review

- Immediate publication on acceptance

- Open access: articles freely available online

- High visibility within the field

- Retaining the copyright to your article

Submit your next manuscript at $\gg$ springeropen.com 